\title{
Kasprzak, M.M., et al., Correction: Effect of Enzymatic Treatment of Different Starch Sources on the in Vitro Rate and Extent of Starch Digestion. Int. J. Mol. Sci. 2012, 13, 929-942.
}

Mirosław Marek Kasprzak ${ }^{1, *}$, Helle Nygaard Lærke ${ }^{1}$, Flemming Hofmann Larsen ${ }^{2}$, Knud Erik Bach Knudsen ${ }^{1}$, Sven Pedersen ${ }^{3}$ and Anne Skov Jørgensen ${ }^{3}$

1 Department of Animal Science, Faculty of Science and Technology, Aarhus University, P.O. Box 50, 8830 Tjele, Denmark; E-Mails: HelleN.Laerke@agrsci.dk (H.N.L.); KnudErik.BachKnudsen@agrsci.dk (K.E.B.K.)

2 Department of Food Science, Faculty of Life Science, University of Copenhagen, Rolighedsvej 30, DK-1958 Frederiksberg C, Denmark; E-Mail: fhl@life.ku.dk

3 Novozymes A/S, Krogshøjvej 36, DK-2880 Bagsværd, Denmark; E-Mails: SvP@novozymes.com (S.P.); anneskovj@gmail.com (A.S.J.)

* Author to whom correspondence should be addressed; E-Mail: MiroslawM.Kasprzak@agrsci.dk; Tel.: +45-8715-4259; Fax: +45-8715-6000.

Received: 28 November 2012; in revised form: 6 December 2012 / Accepted: 17 December 2012 / Published: 18 December 2012

The authors wish to change the description of preparation of samples at Experimental Section on their paper published in $I J M S$ [1].

\section{Section 3.1}

The gelatinization of samples for branching enzyme treatment was not processed by jet cooking at $\mathrm{pH} 6.1$ and $140{ }^{\circ} \mathrm{C}$ with a holding time of 5-7 min, but by the adjustment of $\mathrm{pH}$ to 6.1 at room temperature, heated to $75{ }^{\circ} \mathrm{C}$, adjusted to $\mathrm{pH}=6.1$, kept at $75{ }^{\circ} \mathrm{C}$ for $20 \mathrm{~h}$, adjusted $\mathrm{pH}$ to 3.5 , incubated at $93{ }^{\circ} \mathrm{C}$ for $30 \mathrm{~min}$ and finally adjusted $\mathrm{pH}$ to 5.5 at $93{ }^{\circ} \mathrm{C}$.

Moreover, throughout the paper text and in Tables and Figures the term "jet cooked" should be replaced with "gelatinized". The authors and publisher apologize for the inconvenience.

The corrected version can be accessed at: http://www.mdpi.com/1422-0067/13/12/17292/s1. 


\section{Reference}

1. Kasprzak, M.M.; Lærke, H.N.; Larsen, F.H.; Bach Knudsen, K.E., Pedersen, S.; Jørgensen, A.S. Effect of Enzymatic Treatment of Different Starch Sources on the in Vitro Rate and Extent of Starch Digestion. Int. J. Mol. Sci. 2012, 13, 929-942.

(C) 2012 by the authors; license MDPI, Basel, Switzerland. This article is an open access article distributed under the terms and conditions of the Creative Commons Attribution license (http://creativecommons.org/licenses/by/3.0/). 